DOI https://doi.org/10.30525/978-9934-588-92-1-29

\title{
ПРАВОВІ ЦІННОСТІ В АСПЕКТІ ПРАВОВОЇ ГЛОБАЛІЗАЦІЇ: ТЕОРЕТИКО-ПРАВОВИЙ АНАЛІЗ
}

\section{Тернавська В. М.}

кандидат юридичних наук, дочент, дочент кафедри охорони прачі і навколишнього середовища Київського наџіонального університету будівництва і архітектури м. Київ, Украӥна

Право є одним з найбільш ефективних соціальних засобів організації та забезпечення прогресивного розвитку соціальної системи. Упорядкування суспільних відносин досягається шляхом встановлення державою (прийняття нових чи санкціонування існуючих в суспільстві) правових норм, що виражають систему цінностей суспільства на конкретному етапі його історичного розвитку. Законодавець, встановлюючи у правовій нормі модель поведінки, орієнтується на практичне життя і ті ціннісні канони, що опосередковані певним рівнем моральності і культури конкретного соціального середовища (етичної, політичної, правової). Відповідно у правовій аксіології розрізняють цінності права та цінності у праві [1, с. 31].

Поняття цінності трактується у науковій літературі по-різному, що зумовлюється методологічними відмінностями. Так, цінності розглядаються, по-перше, як щось об'єктивне, існуюче незалежно від людини; по-друге, поняття цінності зводиться до суб'єктивних оціночних суджень довільного характеру, а тому виводиться не 3 об'єктів, а з потреб людини [2, с. 173]. Думається, якщо говорити про матеріальні блага, то сутність цінностей змінюється для кожної нової епохи. Крім того, цінності завжди мали дещо відмінний характер для східної і західної цивілізації. Тим не менш, існують фундаментальні цінності, що властиві людству в цілому в усі часи - життя людини, свобода, людська гідність тощо. Цінності, що уособлюються правом повністю чи частково і зберігають свою життєздатність за допомогою інструментарію права визначаються як цінності права [2, с. 174; 3, с. 48]. Під цінностями у праві, чи власне правовими цінностями, розуміють ті цінності, які правом інтегровані [2, с. 174]. Вважається, що право у даному випадку поєднує етичні, політичні, економічні, світоглядні та інші елементи соціальної культури [1, с. 31]. В той же час, взаємодія і взаємопроникнення норм права і моралі не повинні 
призводити до ціннісного редукціонізму [4, с. 64], тобто механічного включення духовних та інших цінностей у правові.

Сьогодні в умовах трансформації національних правових систем та окремих елементів правової дійсності під впливом правової глобалізації особливого значення набувають конституційні правові цінності. Як свідчить політико-правова дійсність слабкі політичні актори змушені трансформувати свої правові системи не стільки у формі правової інтеграції, скільки у формі правової асиміляції, яка передбачає не лише взаємодію нормативних та організаційних компонентів правових систем, але й прослідковується, перш за все, на рівні компонентів, пов'язаних з вираженням суспільної правосвідомості. Асимілюючий суб'єкт - домінуюча у сучасному світі держава, в обмін на економічну чи воєнну допомогу поширює безпосередньо чи опосередковано правові, ідеологічні та соціокультурні цінності 3 мовчазної згоди органів влади національної держави шляхом пропагандистської роботи та правового виховання [5, с. 20-21]. Пропагандуючи загальновизнані правові цінності (конституціоналізму, демократії, прав і свобод людини тощо), сильні політичні актори нав'язують своє бачення (сценарій) подальшого економічного, політичного, правового і культурного розвитку економічно слабких (залежних) держав. Зберегти свою суверенність, свою національну ідентичність у глобальному світі менш впливові актори можуть саме через національну концепцію конституційних цінностей, що покликана відобразити пріоритетні напрями розвитку держави [6, с. 15]. Критерієм формування системи конституційних цінностей мають стати загальнонаціональні інтереси $[7,8]$. Такої думки дотримується більшість вчених конституціоналістів.

Природу конституційних цінностей та їх сутність слід визначати через призму доктрини конституціоналізму як сукупності ідей, теорій та уявлень про право як механізм розподілу соціальних благ на засадах свободи, рівності, справедливості та поваги гідності людини, а також роль конституції у суспільному житті [9, с. 113]. Як зазначає В. Крусс, визначальне значення для ідентифікації інтерпретації конституційних цінностей мають положення, що становлять аксіологічну композицію преамбули Конституції, оскільки без композиційно-цілісного сприйняття цих цінностей неможливо з'ясувати зміст i ціннісне значення основ конституційного устрою, прав і свобод людини і громадянина інших визначених в Конституції благ $[10$, с. 183, 189].

Система конституційних цінностей може бути представлена, на думку дослідників, як єдність певної сукупності принципів [6, с. 16; 9 , с. 111]. Так, за визначенням А. Кондрашева, конституційні цінності являють собою загальносоціальні принципи (догмати) 3 правовою 126 
конотацією, закріплені в конституції чи такі, що витікають 3 системного тлумачення декількох конституційних приписів, та виявляються у ході інтерпретаційної діяльності органів конституційного правосуддя, які мають за мету забезпечити досягнення такого співвідношення інтересів особи, суспільства і держави, де у пріоритеті $\epsilon$ вища цінність особистісних прав людини в рамках моральних, загальносоціальних, етичних, правових, культурних та інших фундаментальних засад людського буття, що виникли у ході цивілізаційного розвитку [11, с. 22].

В юридичній літературі визначають різні класифікації конституційних цінностей. Зокрема, О. Кушніренко визначає конституційні цінності, що стосуються української державності; конституційні цінності громадянського суспільства, людини та громадянина; конституційні цінності засад діяльності державних органів та органів місцевого самоврядування; конституційні цінності, які відносяться до інших важливих сфер суспільного життя [12, с. 46].

Важливість та пріоритетний характер конституційно-правових цінностей визначається тим, що конституційні цінності, як справедливо зазначає М. Маркуш, є еталоном (мірилом), якісною характеристикою виявлення і оцінки правової моделі організації суспільних відносин, явищ, за допомогою якої не лише визначаються тенденції розвитку конституційних відносин, але й також обгрунтовуються конституційні стратегії вдосконалення законодавства у всіх сферах суспільного життя [13, с. 77], тобто конституційні цінності опосередковують зміст загальнодержавної правової політики.

Таким чином, конституційно-правові цінності $€$ невід'ємним елементом системи конституційного права. Конституційні цінності становлять quinta essentia змісту конституційних принципів і норм, які $\epsilon$ формою втілення і реалізації конституційно-правової політики держави. Однак в науці конституційного права й досі не представлено визначення поняття конституційних цінностей, не визначено ієрархічної системи конституційних цінностей.

\section{Лiтература:}

1. Белинова О. А., Фомин В. Е. Ценность права и ценности в праве. Научный вестник Омской академии МВД России. 2012. № 1 (44). C. 29-33. URL : https://cyberleninka.ru/article/n/tsennost-prava-i-tsennostiv-prave/viewer

2. Рашаева Н. Ю., Гомонов Н. Д. Ценность права в контексте системы ценностей современного российского общества. Вестник Мурманского государственного технического университета. 2006. T. 9. № 1. C. 172-181. URL : https://cyberleninka.ru/article/n/tsennost- 
prava-v-kontekste-sistemy-tsennostey-sovremennogo-rossiyskogoobschestva

3. Михайлов С. В. Систематизация правовых ценностей. Философия права. 2013. № 5 (60). C. 48-55. URL : https://cyberleninka.ru/ article/n/sistematizatsiya-pravovyh-tsennostey

4. Михайлов С. В. Методология правовых ценностей. Философия права. 2013. № 4 (59). C. 62. URL : https://cyberleninka.ru/article/n/ metodologiya-pravovyh-tsennostey

5. Ternavska V. Legal system of Ukraine under conditions of the legal globalization: theoretical and legal analysis. Development of National Law in the Context of Integration into the European Legal Space. Warszawa: Instytut Integracji Europejskiej. BMT Eridia Sp. z o.o. Wydawnictwo Erida, 2018. P. 9-29.

6. Ерофеев А. А. Национальные конституционные ценности и глобализационные процессы. Вестник Челябинского государственного технического университета. 2008. № 31 (132). C. 14-19. URL : https://cyberleninka.ru/article/n/natsionalnye-konstitutsionnye-tsennosti-iglobalizatsionnye-protsessy

7. Притика Д., Потьомкін А. Ювілей конституційного контролю. Закон $i$ бізнес. № 42 (1029). 15.10-21.10.2011. URL : http://zib.com.ua/ua/5666-yuviley_konstituciynogo_kontrolyu.html.

8. Баранов В. М. Деструктивное воздействие права и национальные интересы. Журнал российского права. 2005. № 12. С. 84-87. URL : https://cyberleninka.ru/article/n/destruktivnoe-vozdeystvie-prava-inatsionalnye-interesy

9. Савчин М. Конституційні цінності та конституційна юриспруденція в Україні. Вісник Конституційного Суду України 2010. № 1. C. $111-120$.

10. Крусс В. И. Теория конституционного правопользования. М. : Норма, 2007. 752 c.

11. Кондрашев А. А. Конфликт констиуционных ценностей в теории и практике конституционного правосудия в России. Вестник Сибирского юридического института МВД России. 2018. № 4 (33). C. 21-29.

12. Кушніренко О. Г. Поняття, природа і види конституційних цінностей. Конституиійні цінності: правова природа та практика реалізації : збірник тез Міжнародної науково-практичної конференції [у 2-х част.]. Частина 1. Хмельницький : Хмельницький університет управління та права імені Леоніда Юзькова, 2019. С. 44-46.

13. Маркуш М. Конституційні цінності як основоположні засади в кримінальному процесі України. Вісник Конституційного Суду України. 2013. № 6. С. 73-85. 